instance with the family Lernæopodidæ. Special attention has been directed to the development of certain members of the family, the new facts being recorded in a summary at the end of the paper, which is too long and too technical for quotation in this place.

In No. ${ }_{17} 85$ of the serial just quoted, Mr. P. Bartsch describes several new species of molluscs of the family Vitrinellidæ from the Pacific coast of North and Central America, with illustrations of the shells.

The cyclostomatous polyzoans of the same coast are discussed by Miss A. Robertson in vol. vi., No. I2, of the University of California Zoological Publications, this communication being the third of the series. In addition to the description of new species, the author directs special attention to the ovicel, with particular reference to the investigations of Dr. S. F. Harmer.

A number of polyzoans ranging from the Ordovician to the Cretaceous, and common to Europe and North America, many of which have been included by previous writers in Stomatopora, are referred by Mr. R. S. Bassler in No. 1797 of the Proc. U.S. Nat. Mus. to a new genus under the name of Corynotrypha, for the distinctive characters of which those interested in the subject must consult the original paper.

In the Proceedings of the Royal Irish Academy, vol. xxix. (B), No. 3, Mr. A. W. Stelfox gives an annotated distributional list of the land and fresh-water molluscs of Ireland. The author acknowledges his indebtedness to Dr. Scharff in working out the fauna generally, and to Mr. $\widetilde{B}$. B. Woodward for the discrimination of the species of Pisidium. Fourteen land and fifteen fresh-water species inhabiting Great Britain have not yet been recorded from Ireland, and since most of these belong to the central European fauna, there is considerable probability that they never reached the western island. On the other hand, a Hygromia which apparently belongs to the Cornish outlier of the Lusitanian fauna may turn up on the east coast of Ireland, while search for Limax tenellus should be made in the northern and north-western districts.

The slugs of Natai form the subject of a paper, by $\mathrm{Mr}$. W. E. Collinge, published in the Annals of the Natal Museum, vol. ii., part ii. These are referable to fifteen species, arranged in six families, of which the Aperaidæ, as represented by the exclusively South African genus Apera, is new. Of the five species of this remarkable genus, which has hitherto been included in the Testacellidæ, three are found in Natal. The genus is believed by the author to represent a very primitive type, such resemblances as it shows to the Testacellidæ being probably due to parallelism. It was originally described, in 1879 , as Chlamydephorus, a name which clashes with the mammalian Chlamydophorus. The author states that the latter name was given by Agassiz in 1844 , but it was really proposed in 1824 by Harlan, in the form of Chlamyphorus, and this difference in the original may give rise to the question whether it really preoccupies Binney's Chlamydephorus.

No. 5 of the fifth volume of The Philippine Journal of Science is devoted to a description, by Mr. L. E. Griffin, of a new species of the protozoan genus Euplotes, for which the name Eu. worcesteri is proposed. The typespecimen was found in Igog in water brought to the Manila Laboratory from the neighbouring bay. The species, of which exquisite illustrations are given in the plates accompanying the memoir, is very closely related to Eu. vannus.

A new generic type of crinoid, Thalassocrinus pontifer, from the Philippines is described by Mr. A. H. Clark in No. 1793 of the Proc. U.S. Nat. Mus. It is a stalked form referable to the family Hyocrinidæ, with its nearest relationship, apparently, to Gephyrocrinus.

R. L.

\section{PAPERS ON SYSTEMATIC BOTANY}

$A \mathrm{~N}$ important feature in the revision prepared by $\mathrm{Dr}$ C. B. Robinson of Philippine Urticaceæ, is the discussion of generic limits and relationships. A new genus, Elatostematoides, is proposed for certain species previously referred to Elatostema or Pellionia, and another genus, Astrothalamus, allied to Maoutia. Under Laportea, a NO. 2 I64, VOL. 86 genus of notoriety on account of its stinging hairs, it is mentioned that the hairs are siliceous, and may contain formic and acetic acids; also that prompt relief is afforded by ammonia or carbonate of soda. Many new species are differentiated, notably nine for Laportea and twenty for Elatostema. The first part only of the article appears in the concluding number of the fifth botanical volume of The Philippine Journal of Science.

The second number of the current volume of The Kew Bulletin contains the diagnoses of thirty new African species, chiefly under the genera Protea, Sorocephalus, Loranthus, and Erythrococca, a note by Mr. G. Massee on a lilac disease, and an article on the beechwood industry of the Chilterns by Mr. W. Dallimore. The lilac disease caused by the hyphomycete, Helminthosporium syringae, shows first as a brown stain on either side of the leaf; the stained area extends and darkens, and olive-brown patches of fruit appear; later on, spores are formed in great abundance. Spraying with a solution of potassium sulphide in an early stage serves to check the disease. Mr. Dallimore deals more particularly with the chair-making industry centred in High Wycombe, and the brush-making industry of Chesham.

Recognising the difficulties of delineating the various species of Castilla (Castilloa), Mr. H. F. Pittier designates his careful and well-illustrated revision of the genus in the Contributions from the United States National Herbarium (vol. xiii., No. 7) a preliminary treatment, although his conclusions are based largely upon experience in the field. Ten species are distinguished, of which four from South America are placed in a separate group, while the second consists of Central American species, differing more or less from Castilloa elastica. The practical object of the publication is to make known the diversity of species that may be under cultivation as $C$. elastica. It is noted that $C$. nicoyensis is a good latex producer, and that $C$. costaricana is tapped by the native collectors.

A catalogue of non-herbaceous phanerogams cultivated in the Royal Botanic Garden, Calcutta, published as vol. v. No. $I$, of the Records of the Botanical Survey of India, is not a mere list of species, but is designed to identify and locate every tree or shrub growing there. For this purpose the plan of the garden is divided into squares distinguished by letters and figures, and in addition each plant receives and is labelled with an individual number; thus one specimen of Schleichera trijuga is listed as $\mathrm{O}_{10}$, I64I. At points corresponding to the intersection of lines posts are inserted in the garden to locate the squares. Further, a record of source and history is tabulated for each individual plant to be registered in a filed system, and special sheets have been designed for keeping note of seeds. The present index part will be supplemented by a systematic part furnishing the "stock account" of the garden.

\section{REPORTS ON GLACIOLOG $Y^{1}$}

(I) STUDENTS of glaciology owe a debt of gratitude to M. Rabot, because information on this subject is scattered over a wide field and in unexpected places. To collect that contained in the present number of the Revue must have been a heavy task, and its value is increased by a careful classification. The earlier sections deal with matters such as precipitation, its form and relation to altitude, the rate at which snow melts, avalanches and their consequences, the formation of glaciers, their structures, their dates of movement, and their erosive effects, in regard to which last diverse opinions are quoted. If we can believe Prof. Hans Hess, a glacier deepens its bed by 1 metre in from thirty to fifty years, or, in other words, the erosive power of ice is at least ten times as great as that of running water. Figures are cited to support this conclusion, but a tolerable familiarity with glaciers and their works, for at least that time, leads us to suspect there is something wrong with the figures or the observations.

1 ( $\tau$ ) Revue de Glaciologie. No. 3 (avril 1903- $\mathrm{r}^{\mathrm{er}}$ janvier 1907). By Charles Rabot (Mémoires de la Société Frihourgeoise des Sciences Naturelles, vol. v.. Band v.; Géologie et Géographie). Pp. $344+30$ figures. Fribourg, Suisse, 1909.) Price 6 francs.

(2) Les Variations périodiques des Glaciers. $\mathrm{XV}^{\mathrm{me}}$ Rapport, rgog. Rédigé par Dr. E. Brückner et E. Muret. Extrait des Annales de Glaciologie, t. v. Janvier: 19rI. Pp. 177-202. (Berlin : Borntrager Frères, rgrr.) 